\title{
Android-Based Edu Game Media on Mathematical Communication Skill of Elementary School Students
}

\author{
Masniladevi ${ }^{1}$, Y Helsa ${ }^{2}$, S Rahmadhani ${ }^{3}$ \\ Universitas Negeri Padang, Jl. Prof Dr. Hamka Air Tawar, Padang, Indonesia ${ }^{1,2,3}$
}

\{masniladevi@fip.unp.ac.id $\left.{ }^{1}\right\}$

\begin{abstract}
The background of this research is the development of android-based edugame media for elementary school students. The purpose of this study was to determine the effect of android-based edugame media on mathematical communication of elementary school students. This research is a quasiexperimental study. The results showed that the influence of using Androidbased edugame media on mathematical communication skills of elementary school students. The implication of this study as a reference by elementary school teachers to use edugame media to improve mathematical communication skills of elementary school students.
\end{abstract}

Keyword : Android- Based, Games, Students

\section{Introduction}

Mathematics must be taught in elementary school [1]. Mathematics has benefits related to student life [2]. One of the characteristics of current students' lives is that students live in an Industry 4.0 era, which requires students to understand science and technology. Mathematics is one of the influential studies in science and technology development [3-4]. Therefore students are required to develop and master technology in the future. Given the importance of mathematical science, mathematics must be taught in a learning process [5].

Mathematical learning is not just related to an understanding of symbols and numbers [6]. Mathematical learning can consist of problem-solving, reasoning, connection, representation and communication [7]. These five competencies must be developed for students to reach the learning objectives of mathematics. However, the process of learning mathematics focuses more on understanding mathematical symbols and numbers thus these competencies have not been developed to the fullest. This includes mathematical communication skills.

Mathematical learning not only teaches a mathematical concept to students but a learning process built by a teacher to develop students' mathematical communication skills to understand the ideas contained in symbols, diagrams, and other media and pour these ideas to solve the problems found [8]. Mathematical communication is a learning process built by the teacher to develop students' mathematical communication skills to understand ideas contained in symbols, diagrams, and other media and to express these ideas to solve the problems found [9].

Mathematics learning is a learning process that is built by the teacher to develop students' mathematical communication skills to understand ideas contained in symbols, diagrams, and 
other media and express these ideas to solve the problems they find [10]. Mathematical communication is important taught to elementary school students. Mathematical connection skills can shape written, oral, graphic and picture situations into algebra; reflect thoughts about mathematical ideas in various situations, develop an understanding of mathematical ideas, practice reading, listening and writing skills in expressing ideas, learn mathematical ideas through conjectures and convincing reasons and understand the value of rotation and the role of mathematics in developing mathematical ideas [11] .

Besides mathematical communication has two important roles, namely as mathematics as language and mathematics as social activity [12]. Mathematics as a language means that mathematics is not only a tool for thinking, finding patterns, solving problems but also for communicating ideas clearly, smoothly and precisely. Mathematics as a social activity means that mathematics can cause and create social interaction through communication between students and teachers. Based on this, the development of communication for elementary school students is needed.

However, based on observations during the mathematics learning process, problems were found regarding mathematical communication. This problem arises from the learning process carried out by the teacher which requires students to quickly understand learning without providing opportunities for students to communicate their ideas properly. The ongoing learning process looks monotonous and boring for students, the teacher only gives explanations related to the material and provides exercises. Students tend to be lazy to pay attention to when teacher explaining learning because there is nothing attracts their interest and motivation for enthusiasm in learning, as a result when answering questions they do it carelessly.

To solve this problem, we must present creative efforts according to the students' characteristics hence students' mathematical communication skills can develop properly. Times have produced a native digital generation. A native digital generation is a generation lives in 1998 until now when technology is developing [13]. The characteristics of digital generation are born in a digital technology environment including elementary school students. Activities carried out are always attached to digital technology, and consider digital technology to be an inseparable part of his life [14]. Another characteristic of this generation is they really enjoy playing online, as well as the need, the desire to always be connected to the internet [15]. Ibrahim stated that a native digital generation is educated in an interactive digital technology environment, with a solitary character because they spend more time with gadgets than socializing directly[16].

One of the creative efforts in learning for the native digital generation is by presenting learning media that attract students' interest and motivation and can be used as part of gadgets used daily. The media is an android-based edugame media. This learning media was chosen because it is following the characteristics of elementary school students currently in the native digital generation.

Edugame is a game containing educational values [17]. Through edugame students will learn from the game. Edugame is popular because it matches the characteristics of elementary school students. Primary school students are in the concrete operational phase so that one of the principles of student learning is learning while playing [18]. Edugame has several advantages such as increasing the independence of student learning, student understanding, interaction and improving problem-solving skills [19-22].

Android learning media is a learning medium using the android system on cellular telephones [23]. Android is used as a learning medium to facilitate learning, increase the 
desire of students to learn and improve the learning process that affects good learning outcomes [24].

In addition, Android-based edugame media has the benefit of growing children's learning motivation because students like animation media. This animation makes the learning atmosphere more relaxed and enjoyable so that students easily understand the concept of learning and improve their mathematical communication skills [25].

This edugame media has been previously developed by researchers. This media has been declared valid by experts and suitable for elementary school students. Therefore, the purpose of this study is to determine the effect of an Android-based edugame media that have been previously developed on the mathematical communication skills of elementary school students.

\section{Research Methodology}

This type of research in this study is quantitative with a quasi-experimental method in the form of inequivalent post-test design. In this study, there are two sample classes, each of which acts as an experimental class and a control class. The experimental class was given learning by using a scientific approach assisted with Android-based edugame media while the control class was conducted learning using a scientific approach assisted with existing media in student books. Then, each class will be given a final test (post-test) to determine the effect of Android-based media edugames on students' mathematical communication skills. The population in this study were all class IV at Elementary School in Padang city with 44 students consisting of class a and class b.

The instrument used in this study was a test instrument. The test given is in the form of 10 essays arranged based on indicators of ability. The data analysis in this study was the t-test carried out after the prerequisites t-test. The prerequisite t-test stated whether the data is homogeneous and normal in mathematical communication.

\section{Result and Discussion}

This study uses prerequisite tests and hypothesis tests. The prerequisite test analysis is carried out to see whether the data is normally distributed and homogeneous. Therefore, it is necessary to test the normality of the experimental class and the control class. After confirming the data distribution is normal and homogeneous, the hypothesis test is conducted. The normality test results are in the table below.

Table 1. Calculation Results of Normality Test with Liliefors in Experimental

\begin{tabular}{clccccc}
\multicolumn{7}{c}{ and Control Classes (Posttest) } \\
\hline No & Class & $\mathbf{N}$ & $\boldsymbol{\alpha}$ & $\mathbf{L}_{\text {count }}$ & $\mathbf{L}_{\text {table }}$ & Description \\
\hline 1. & Experimental & 24 & 0,05 & 0,1223 & 0,173 & Normal \\
2. & Control & 24 & 0,05 & 0,0688 & 0,173 & Normal \\
\hline
\end{tabular}

From table 1, it can be seen that the calculation of Liliefors test in experimental class is 0.1223 which is smaller than the Ltable of 0.173 for 0.05 . While, for the control class, Lcount value is 0.0688 which is smaller than the Ltable of 0.173 for 0.05 . Based on these data, it can 
be concluded that the experimental class and the control class posttest is derived from normally distributed data. Next is homogeneity test, the results can be seen in the table below.

Table 2. Calculation Results of Homogeneity Test with Fisher in Experimental

\begin{tabular}{cccccc}
\multicolumn{6}{c}{ and Control Classes (Posttest) } \\
\hline No & \multicolumn{1}{c}{ Class } & $\boldsymbol{\alpha}$ & $\mathbf{F}_{\text {count }}$ & $\mathbf{F}_{\text {Table }}$ & Description \\
\hline 1. & Experimental & 0,05 & 2,43 & 3,31 & Homogeneous \\
2. & Control & & & & \\
\hline
\end{tabular}

From the above table, it can be concluded that the posttest results the two classes is $\mathrm{F}_{-}(\max )$ count $\leq \mathrm{F}_{-}(\max )$ table $=2.43 \leq 3.31$ then the data is categorized homogeneous.

After the normality and homogeneity tests, it is known that the data is normally distributed and homogeneous. Therefore, the hypothesis test uses the t-test for two groups from two unpaired samples. The results of the hypothesis test can be seen in the table below.

Table 3. Test Results With T-Test

\begin{tabular}{clccc}
\hline No & Class & Average value & $\mathbf{T}_{\text {count }}$ & $\mathbf{T}_{\text {table }} \boldsymbol{\alpha} \mathbf{0 , 0 5}$ \\
\hline 1. & Experimental & 68,13 & 3,24 & $1,67866$. \\
2. & Control & 53,95 & & \\
\hline
\end{tabular}

From the above table, $\mathrm{t}$ count $>\mathrm{t}$ table is $3.24>1.67866$, so that $\mathrm{HO}$ is rejected and $\mathrm{Ha}$ is accepted. Then, it can be concluded that the results of classroom mathematical communication skills using android-based edugames media are higher than those without android-based edugames media. It can be stated that the Android-based media edugames affect the mathematical communication skills of elementary students.

The game has a very close relationship with children world, especially elementary school children. Elementary school-age children are in the concrete operational period. At this time, elementary school students will be better off using the principle of playing while learning. Therefore, the teacher plays an important role in processing the learning following this phase.

An educational game is one of the learning media that can increase a learning quality including mathematics learning. This is supported by the research results that edugame media can improve mathematical communication capability. This is supported by the fact that Edugame can visualize real problems in life [26]. Problems in mathematics learning are presented in a game visualization form. Hence students are easy to understand the problem. The process of understanding the problem will help students develop mathematical communication skills.

Edugame media can train cognitive abilities, motor skills and student creativity [27]. This capability will encourage improving mathematical communication skills [28]. Students who can understand the mathematical concepts in edugame will make it easier for them to communicate the material in mathematics both verbally and in writing. Besides, edugame media can increase student motivation in learning. Motivation is very necessary for the learning process. Motivation can influence students' mathematical communication skills [29]. Students with high motivation in learning will affect the learning process.

Besides, the use of android media also affects students' mathematical communication abilities. Android is an application operating system resided on smartphone devices [30]. Android media is very closely related to students nowadays. Android is easy to use and often used by students in everyday life. This is the foundation that causes Android to improve the mathematical communication abilities of elementary school students. Android-based media is 
an effective media to appeal to students. This is because this media presents animations with audio and visual characteristics thus it matches the characteristics of students [31].

\section{Conclusion}

Based on the data analysis results, it showed the average value obtained in the experimental class was 68.13 while the average value obtained in the control class was 53.95. Based on the data analysis, tcount $>$ ttable, which is 3.24>1.67866. It can be concluded that there is a significant influence on the ability to understand mathematical concepts taught using Android-based Edugames media compared to control classes that only use media on student books.

\section{Acknowledgment}

I would like to thank Universitas Negeri Padang for granting permission for this research.

\section{References}

[1] Kenedi A K, Hendri S, Ladiva H B and Nelliarti N 2018 Numeracy Journal 5226

[2] Kenedi A K. 2018 Literasi Matematis Dalam Pembelajaran Berbasis Masalah (UNP Press: Padang)

[3] Kenedi A K, Helsa Y and Hendri S 2018 Jurnal Inovasi Pendidikan Dan Pembelajaran Sekolah Dasar 29

[4] Mansur M., Helsa, Y., \& Kenedi A K 2017 International Conference of Early Childhood Education vol 169 (Padang/Atlantis Press) p 304

[5] Ariani Y and Kenedi A K 2018 Jurnal Inspirasi Pendidikan 825

[6] Minarni A, Napitupulu E and Husein R 2016 Journal on Mathematics Education 743

[7] Kenedi A K, Helsa Y, Ariani Y, Zainil M and Hendri S 2019 Journal on Mathematics Education 1069

[8] Paridjo W and St B 2017 Journal of Mathematics 1360

[9] Qohar A and Sumarmo U 2013 Indonesian Mathematical Society Journal on Mathematics Education 459

[10] Sari D M 2017 Infinity Journal 6183

[11] National Council of Teachers of Mathematics 2003 Principle and Standards for School Mathematics (Reston, VA: NCTM)

[12] Baroody A J 993 Problem solving, reasoning and communicating, K-8: Helping children think mathematically (New York: Macmillan Publishing Co.)

[13] Jones C, Shao B, and Keynes M 2011 Open University Review in United Kingdom 1 56.

[14] Prensky M 2001 On the horizon 95

[15] Van Eck R 2006 EDUCAUSE review 4116.

[16] Ibrahim I S 2011 Kritik budaya komunikasi (Yogyakarta: Jalasutra)

[17] Backlund P and Hendrix M 2013 5th international conference on games and virtual worlds for serious applications (Poole/IEEE) $\mathrm{p} 1$

[18] Kiswanto A 2017 9th International Conference for Science Educators and Teachers vol 118 (Semarang/ Atlantis Press) 
[19] Hssina B, Erritali M, Bouikhalene B and Merbouha A 2014 International Journal of Innovation and Applied Studies 91531.

[20] Suharyati H and Helena G 2018 International Journal of Multi Discipline Science 1 169

[21] Mokhtar R and Zin N A M 2016 International Journal of Future Computer and Communication 5176.

[22] Risnawati et al 2018 J. Phys.: Conf. Ser. 1028012130

[23] Azmi N, Maryono D and Yuana R A 2017 Indonesian Journal of Informatics Education 161

[24] Ramadhani D G, Mulyani B, and Utomo S B 2016 Jurnal Pendidikan Kimia 516

[25] Ramansyah W, Sari A K, Panich P and Akbar N H 2018 Journal of Intensive Studies on Language, Literature, Art, and Culture 299

[26] Hakim A R, Andrea R and Antoni D 2016 Sebatik 1610

[27] Malau E P and ES A J 2018 Jurnal Teknik Informatika UNIKA Santo Thomas 326

[28] Pratiwi D D 2015 Al-Jabar: Jurnal Pendidikan Matematika 6131

[29] Khamid A and Santosa R H 2016 PYTHAGORAS: Jurnal Pendidikan Matematika 11 111

[30] Ependi U and Sopiah N 2015 Matrik 17109

[31] Delkisyarangga B 2017 Jurnal Pendidikan Teknik Mekatronika 740. 